\title{
GENETIC STUDIES ON ISOZYMES OF THE INTEGUMENT ESTERASE IN THE SILKWORM, BOMBYX MORI L.
}

\author{
MASAHARU EGUCHI AND NARUMI YOSHITAKE**
}

Faculty of Textile Fibers, Kyoto University of Industrial Arts and Textile Fibers, Kita-ku, Kyoto, and *Faculty of Agriculture, University of Tokyo, Bunkyo-ku, Tokyo

\section{Received December 1, 1965}

In recent years a number of cases of protein polymorphisms in insects have been reported. During past few years the authors have carried out genetic and physiological studies on isozymes of several enzymes in the silkworm, Bombyx mori L., by means of agar gel electrophoresis, and showed that the productions of acid phosphatase and esterase isozymes in blood are controlled by codominant alleles respectively (Yoshitake and Akiyama 1964, Eguchi, Yoshitake and Kai 1965). Yoshitake (1964) studied the midgut alkaline phosphatase in larvae of the silkworm, and described that two isozymes detected are controlled by different genes located at different loci. Eguchi and Sugimoto (1965) discerned five isozymes, two deep and three faint bands on agar gel zymograms of esterase in extract of the larval integument, and observed that their enzyme activities decreased with pupation.

Genetic studies on the esterase isozymes in insects have been carried out by various investigators (Veldhuis and Asperen 1963, Wright 1963, Wright and MacIntyre 1963, Asperen 1964, Ogita 1965a, 1965b), but comparative studies of the enzyme by organs in a same species are few. At present the authors are comparing zymograms of the enzyme froin extract of various tissues of silkworm larvae. The present study was specially designed to detect the difference of main esterase isozymes in the silkworm by strains and to reveal the mode of inheritance of these isozymes in the larval integument.

\section{MATERIALS AND METHODS}

The 202 different strains of the silkworm obtained from the Sericulture Experiment Stations of the Ministry of Agriculture, Shinjo, Kobuchizawa and Miyazaki were used for the present study. Individuals at the fifth larval stage were utilized as the experimental materials. For the survey work of various esterase isozymes among silkworm strains four or more individuals were studied for each strain.

Dissecting the larval body and removing internal organs, the integument was washed with water and then ground with distilled water in a mortar. The homogenate was put into the hollow porcelain plate. In order to prevent streaking from cell 
fragments in the electrophoresis, a small piece of thin paper (toilet tissue "Scott" Sanyo Co. Ltd.) was placed over the homogenate to act as a filter, and the filtered homogenate was absorbed into cotton thread.

Except for a few slight modifications, the electrophoretic techniques used were the same as those described by Ogita (1962, 1963 and 1964). Electrophoresis was carried out on a glass plate covered with a $0.8 \mathrm{~mm}$ layer of buffered agar gel $(0.7 \%$ agar and $2 \%$ polyvinylpyrrolidone in phosphate buffer at $\mathrm{pH} 6.8$, ionic strength 0.025 ). A constant voltage of $13 \mathrm{~V} / \mathrm{cm}$ was applied for 150 minutes at $5^{\circ} \mathrm{C}$. On completion of the electrophoresis the mixture of $4 \mathrm{ml}$ of $1 \% \quad \beta$-naphtyl acetate in acetone and $20 \mathrm{ml}$ of $0.5 \%$ naphthanil diazo blue $\mathrm{B}$ in phosphate buffer ( $\mathrm{pH} 6.8$, ionic strength 0.025 ) was poured on the surface of the agar gel $(16 \times 12 \mathrm{~cm})$, and incubated at $37^{\circ} \mathrm{C}$ for a few minutes. Red bands appearing on the agar gel indicated the presence of esterase.

The method for measuring the esterase activity was essentially the same as those described by other investigators (Nachlas and Seligman 1949, Afsharpour and O'Brien 1963, Ozaki and Koike 1965). One hundred $\mathrm{mg}$ of the fresh tissue was homogenized with $5 \mathrm{ml}$ of phosphate buffer $(0.1 \mathrm{M}, \mathrm{pH} 7.0)$ in a mortar, centrifuged at 3000 r.p.m. for 5 minutes and the supernatant was used as enzyme solution.

After $2 \mathrm{ml}$ of the substrate solution ( $10 \mathrm{mg}$ of $\beta$-naphtyl acetate, $2 \mathrm{ml}$ of acetone, $50 \mathrm{ml}$ of phosphate buffer and $48 \mathrm{ml}$ of distilled water) was preincubated for 5 minutes at $37^{\circ} \mathrm{C}, 0.1 \mathrm{ml}$ of the enzyme solution was added and the mixture was incubated for 10 minutes at $37^{\circ} \mathrm{C}$, then $0.5 \mathrm{ml}$ of a freshly prepared $0.4 \%$ naphthanil diazo blue $\mathrm{B}$ solution was added. After a few minutes, $0.5 \mathrm{ml}$ of $20 \%$ trichloroacetic acid was added. The mixture was shaken with $4.5 \mathrm{ml}$ of ethyl acetate and centrifuged for 5 minutes. The solution was measured in a Shimazu-Bausch \& Lomb Spectronic colorimeter at $540 \mathrm{~m} \mu$.

\section{RESULTS AND DISCUSSION}

The electrophoretic mobility of the integument esterase in the silkworm showed variations among different strains as the samples are shown in Fig. 1. Zymograms obtained were classified into ten different types as represented diagrammatically in Fig. 2.

As can be seen in Fig. 1, the esterases from the larval integument of individual silkworms were either divided into two or three components on the zymogram, or not divided any further and detected as a single band. All these isozymes are classified into three kinds according to the electrophoretic mobility and they are designated $\mathrm{A}$, $\mathrm{B}$ and $\mathrm{C}$. The existence of individuals with the integument having three kinds of esterase isozymes simultaneously is quite different from the result of study for blood esterase, in this case only the maximum of two kinds of isozymes was detected from an individual (Eguchi, et al. 1965). As to the $\mathrm{AB}$ and $\mathrm{AC}$ types of the integument esterase the following two cases were observed: (1) the two bands on a zymogram 

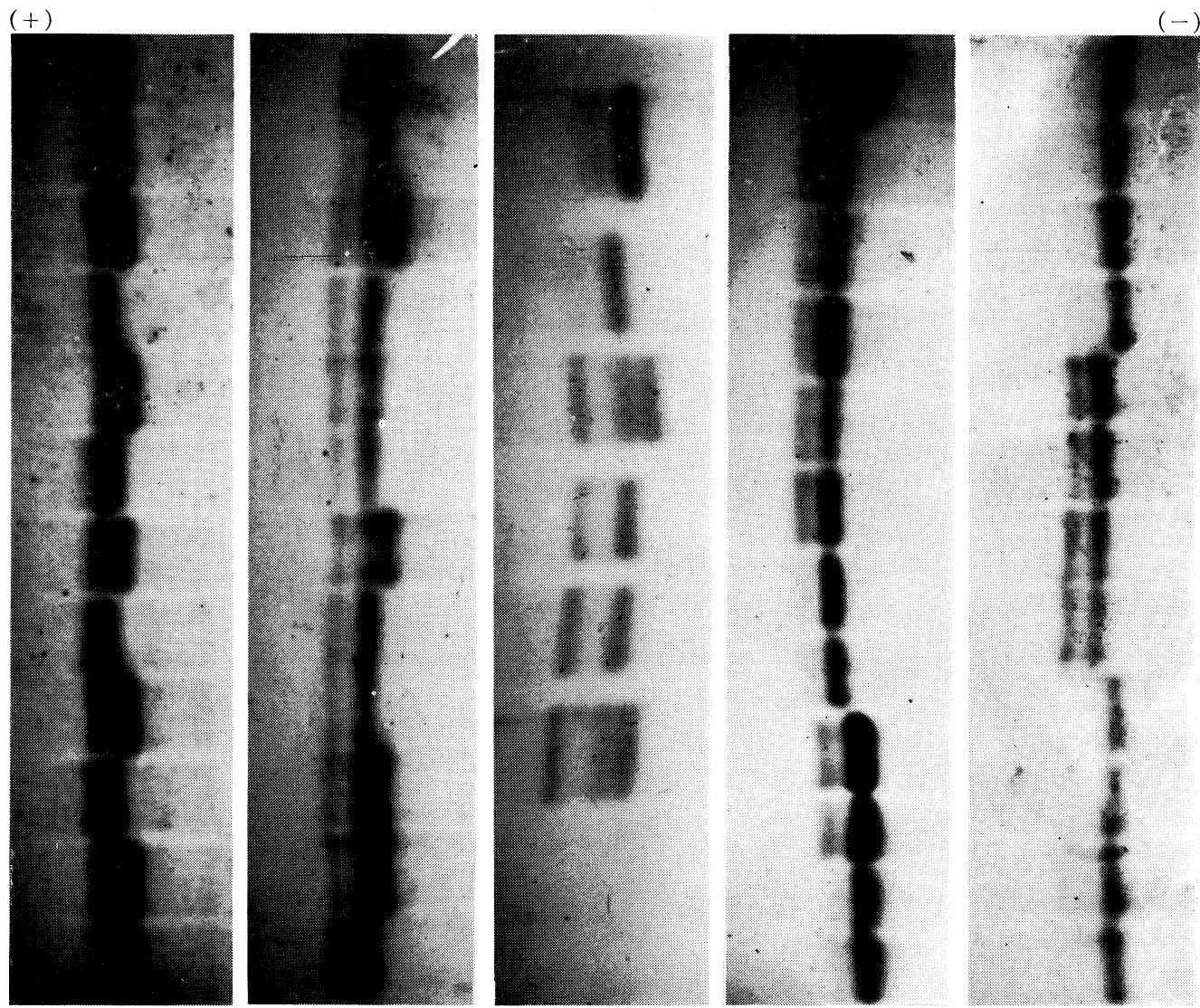

Fig. 1. Photographs of the various esterase types in the Integument. In each of five photographs the origin and cathode are at the right hand and the anode at the left.

showed an equal intensity, and (2) the band $\mathrm{B}$ or $\mathrm{C}$ colored deeper than the band $\mathrm{A}$. In the latter case, the genotypes of $\mathrm{AB} / \mathrm{B}$ and $\mathrm{AC} / \mathrm{C}$ are conceivable. The difference in tint of each band was not always clear in the case of $\mathrm{ABC}$ type.

Activities of esterase in the larval integument were compared by individuals whose genotypes for esterase isozymes are different. The results are shown in Table 1.

Table 1. Esterase activity of integument extracts from several enzyme types

\begin{tabular}{|c|c|c|c|c|}
\hline \multirow{2}{*}{ Strain } & \multirow{2}{*}{ Parents } & \multicolumn{3}{|c|}{ Offspring } \\
\hline & & Phenotype & Genotype & Esterase activity (Absorbance) \\
\hline 1 & $\mathrm{~B} \times \mathrm{B}$ & B & $\mathrm{B} / \mathrm{B}$ & 0.325 \\
\hline 2 & $B \times B$ & B & $\mathrm{B} / \mathrm{B}$ & 0.340 \\
\hline 3 & $\mathrm{AC} \times \mathrm{C}$ & A C & $\mathrm{AC} / \mathrm{C}$ & 0.510 \\
\hline 4 & $\mathrm{AB} \times \mathrm{AB}$ & A B & $\mathrm{AB} / \mathrm{AB}$ & 0.650 \\
\hline 5 & $\mathrm{AB} \times \mathrm{AB}$ & A B & $\mathrm{AB} / \mathrm{AB}$ & 0.620 \\
\hline 6 & $\mathrm{AC} \times \mathrm{AC}$ & $\mathrm{AC}$ & $\mathrm{AC} / \mathrm{AC}$ & 0.690 \\
\hline 7 & $\mathrm{AC} \times \mathrm{AC}$ & A C & $\mathrm{AC} / \mathrm{AC}$ & 0.710 \\
\hline
\end{tabular}




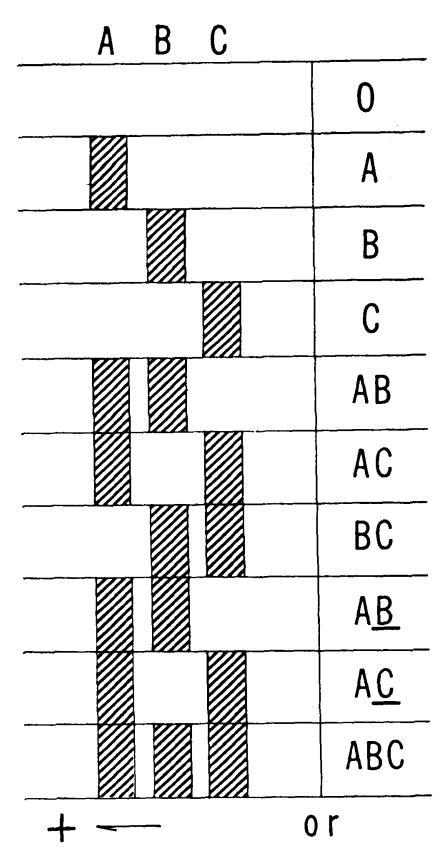

Fig. 2. Diagrammatic representation of integument esterase zymograms. $\mathrm{AB}$ and $\mathrm{A} \underline{\mathrm{C}}$ shows that the intensity of $\mathrm{B}$ or $\mathrm{C}$ band is deeper than that of A band.

The activities in the compound types, such as $\mathrm{AB}(\mathrm{AB} / \mathrm{AB})$ or $\mathrm{AC}(\mathrm{AC} / \mathrm{AC})$, were almost twice as high as that in the single band type $(\mathrm{B} / \mathrm{B})$. The activity in $\mathrm{AC}(\mathrm{AC} / \mathrm{C})$ type was roughly $3 / 2$ of that in the single type.

Fig. 3 shows the activities of esterase in the 24 individuals segregated from the cross $(B \times A B) \times(B \times$ $A B)$. From these data, the segregants are classifiable into three groups; 6 high, 11 medium and 7 low. This result approximately agrees with the theoretical segregation ratio $\mathrm{B} / \mathrm{B} 1: \mathrm{AB} / \mathrm{B} 2: \mathrm{AB} / \mathrm{AB} 1$.

Results described above suggest that some duplications of an esterase gene had taken place during the evolutionary process of this insect species. Such a possibility in genes for the amylase in Drosophila melanogaster has been proposed by Kikkawa (1964).

Then crossing experiments were performed to determine the mode of inheritance of the integument esterase isozymes and the results are shown in Table 2.

In the homogenate of the larval integument of the offspring from the cross $\mathrm{B} \times \mathrm{B}$ or $\mathrm{C} \times \mathrm{C}$, only one kind of isozyme identical with that of the parental strain was detected respectively. From the heterozygotes, B/C, both esterase $\mathrm{B}$ and $\mathrm{C}$ isozymes with an equal intensity were found. From any mating type no heterozygote with a hybrid form of esterases, which might be detected as an

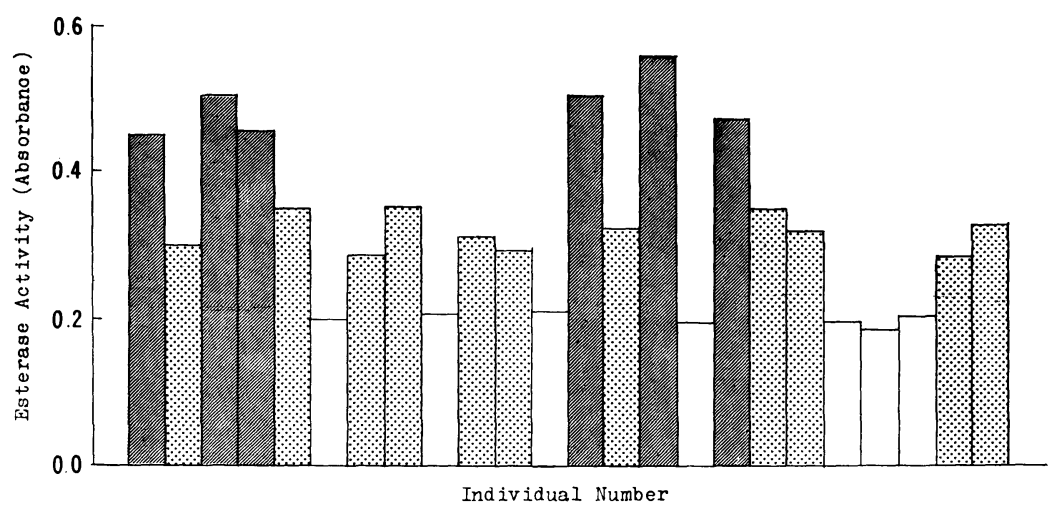

Fig. 3. Esterase activity in the individual larvae segregated from $(B \times A B)$ Sib. mating. 
Table 2. Crosses made to determine the mode of inheritance of the integument esterase variants

\begin{tabular}{|c|c|c|c|}
\hline \multicolumn{2}{|r|}{ Parents } & \multicolumn{2}{|c|}{ Offspring } \\
\hline Phenotype & Genotype presumed & Esterase pattern & \multirow{2}{*}{$\frac{\text { Total }}{33}$} \\
\hline $\mathrm{B} \times \mathrm{B}$ & $\mathrm{B} / \mathrm{B} \times \mathrm{B} / \mathrm{B}$ & $\mathrm{B}: 33$ & \\
\hline $\mathrm{C} \times \mathrm{C}$ & $\mathrm{C} / \mathrm{C} \times \mathrm{C} / \mathrm{C}$ & $\mathrm{C}: 33$ & 33 \\
\hline $\mathrm{B} \times \mathrm{C}$ & $\mathrm{B} / \mathrm{B} \times \mathrm{C} / \mathrm{C}$ & $\mathrm{BC}: 10$ & 10 \\
\hline $\mathrm{AB} \times \mathrm{A}$ & $\mathrm{AB} / \mathrm{AB} \times \mathrm{A} / \mathrm{A}$ & $\mathrm{AB}: 6$ & 6 \\
\hline $\mathrm{AB} \times \mathrm{AB}$ & $\mathrm{AB} / \mathrm{AB} \times \mathrm{AB} / \mathrm{AB}$ & A B : 15 & 15 \\
\hline $\mathrm{AC} \times \mathrm{C}$ & $\mathrm{AC} / \mathrm{AC} \times \mathrm{C} / \mathrm{C}$ & A C : 18 & 18 \\
\hline $\mathrm{AC} \times \mathrm{AC}$ & $\mathrm{AC} / \mathrm{AC} \times \mathrm{AC} / \mathrm{AC}$ & $\mathrm{AC}: 12$ & 12 \\
\hline \multirow[t]{2}{*}{$\mathrm{AB} \times \mathrm{C}$} & $\mathrm{AB} / \mathrm{B} \times \mathrm{C} / \mathrm{C}$ & $\mathrm{ABC}: 10$ & \\
\hline & & B C : 12 & 22 \\
\hline \multirow[t]{2}{*}{$\mathrm{ABC} \times \mathrm{B}$} & $\mathrm{AB} / \mathrm{AC} \times \mathrm{B}$ & A B C : 28 & \\
\hline & & A B : 36 & 64 \\
\hline
\end{tabular}

intermediate band between original two bands on a zymogram, was produced. From the crosses between phenotypes $\mathrm{AB}$ and $\mathrm{A}$ or $\mathrm{AC}$ and $\mathrm{C}$, only the $\mathrm{F}_{1}$ hybrids with the esterase of $\mathrm{AB}$ or $\mathrm{AC}$ appeared but $\mathrm{A}$ or $\mathrm{C}$ was not observed at all. This fact may suggest that the genetic constitution of individuals with the phenotypes $A B$ or $A C$ was homozygotic $\mathrm{AB} / \mathrm{AB}$ or $\mathrm{AC} / \mathrm{AC}$, but not heterozygotic $\mathrm{A} / \mathrm{B}$ or $\mathrm{A} / \mathrm{C}$. The results from crosses $\mathrm{AB} \times \mathrm{AB}$ and $\mathrm{AC} \times \mathrm{AC}$ can also be explained by the same assumption. The crosses between phenotypes $\mathrm{ABC}$ (the band $\mathrm{A}$ was deeper in color than $\mathrm{B}$ or $\mathrm{C}$ ) and $\mathrm{B}$ produced progenies with $A B C$ and $A B$ types. Therefore, the genotypes of the parents were assumed to be $\mathrm{AB} / \mathrm{AC}$ and $\mathrm{B} / \mathrm{B}$.

Series of experiments described above permit the following genetic interpretation. Six allelic genes, Ies ${ }^{D}, I e s^{A}, I e s^{B}, I e s^{C}, I e s^{A B}$ and $I e s^{A C}$, exist at a locus which controls the production of esterase isozymes, $\mathrm{O}, \mathrm{A}, \mathrm{B}, \mathrm{C}, \mathrm{AB}$ and $\mathrm{AC}$, in the silkworm integument. Individuals homozygous for $I e s^{A}, I e s^{B}$ or $I e s^{C}$ show a single esterase band, A, $\mathrm{B}$ or $\mathrm{C}$, on a zymogram, and those for $I e s^{A B}$ or $I e s^{A C}$ show double bands A and $\mathrm{B}$ or $\mathrm{A}$ and $\mathrm{C}$. From the individual homozygous for $\mathrm{Ies}^{\circ}$ gene no active esterase can be detected. In the heterozygote the two alleles show no dominance, i.e., they are codominant alleles, each gene controlling the production of a similar, but not identical protein. The existence of the compound type of gene $I e s^{B C}$ which might produce the $\mathrm{B}$ and $\mathrm{C}$ type isozymes together at a single dose has never been proved. If such a gene exists in the silkworm populations, the frequency must be quite low.

The frequency of each Ies gene in the silkworm was investigated using 202 strains. Eighty nine strains (44.0\%) were found to be $\mathrm{C}$ type, $24.8 \%$ belonged to $\mathrm{B}$ type, $20.8 \%$ were $\mathrm{AC}$ type and $8.4 \%$ were $\mathrm{AB}$ type. Two strains (1.0\%) each with Ies $^{\circ}$ or Ies $^{\mathrm{A}}$ gene were respectively found. The fact that the A isozyme was mostly found in individuals of compound type $(\mathrm{AB}$ and $\mathrm{AC})$ and rarely detected as a single type $(\mathrm{A})$ 
may mean that individuals with only the A type esterase have lower adaptability to the environment than those with other types of isozymes.

From examinations of the lactate dehydrogenase zymograms of the different tissues of the mouse, Markert (1963) indicated that the specific characteristics of each tissue or organ is based upon the specific proportions of the several isozymes present in the tissue and not upon the presence or absence of an isozyme, and the concept of a tissue-specific isozyme is entirely inappropriate. In the silkworm, the number of isozymes detected from the integument esterase and the mode of inheritance of them are different from those of blood esterase. This fact supports the view that there exist tissue-specific isozymes which may be controlled by different genes. Experiments to reveal the mode of inheritance of the esterase isozymes in the silkgland, intestine and Malpighian tubes are being carried out.

\section{SUMMARY}

Electrophoretic variations in the integument esterase of the silkworm, Bombyx mori L., were found. The esterase was classified into the six fundamental isozyme types, $\mathrm{O}, \mathrm{A}, \mathrm{B}, \mathrm{C}, \mathrm{AB}$ and $\mathrm{AC}$. The mode of inheritance of these isozymes was studied and confirmed that they are controlled by codominant alleles, Ies ${ }^{2}, I e s^{A}, I e s^{B}, I e s^{C}, I e s^{A B}$ and $I e S^{4 C}$ respectively. The esterase activities in individuals with compound types, $\mathrm{AB}$ or $\mathrm{AC}$, were approximately twice as high as that in the single band type. These individuals seemed to be homozygotes for the genes $I e S^{A B}$ or $I e S^{A C}$, which might be occurred by the duplication of primitive genes, $I e s^{A}$ and $I e s^{B}$ or $I e S^{A}$ and $I e s^{C}$.

Frequencies of these codominant genes in the silkworm population were calculated from the results of 202 strains investigated. The frequencies of the Ies genes $C, B$, $A C, A B, O$, and $A$ were $0.44,0.25,0.21,0.08,0.01$ and 0.01 , respectively.

\section{LITERATURE CITED}

Afsharpour, F., and R. D. O'Brien, 1963 Column chromatography of insect esterases. J. Insect Physiol. 9: 521-529.

Asperen, K. van, 1964 Biochemistry and genetics of esterases in houseflies (Musca domestica) with special reference to the development of resistance to organophosphorus compounds. Entomol. Exp. Appl. 7: 205-214.

Eguchi, M., N. Yoshitake, and H. Kai, 1965 Types and inheritance of blood esterase in the silkworm, Bombyx mori L. Japan. J. Genetics 40: 15-19

Eguchi, M., and T. Sugimoto, 1965 Changes in esterase zymograms in the silkworm, Bombyx mori L., during development. J. Insect Physiol. 11: 1145-1149.

Kikkawa, H., 1964 An electrophoretic study on amylase in Drosophila melanogaster. Japan. J. Genetics 39: 401-411.

Markert, C. M., 1963 Epigenetic control of specific protein synthesis in differentiating cells. In " $\mathrm{Cy}$ todifferentiation and macromolecular synthesis" (M. Locke, ed.) pp. 65-84. Academic press, New York. 
Nachlas, M. M., and A. M. Seligman 1949 Evidence for the specificity of esterase and lipase by the use of three chromogenic substrates. J. Biol. Chem. 181: 343-355.

Ogita, Z., 1962 Genetico-biochemical analysis on the enzyme activities in the house fly by agar gel electrophoresis. Japan. J. Genetics 37: 518-521.

Ogita. Z., 1963 Separation and revelation of isozymes by means of the thin layer electrophoresis. Nucleus and Cytoplasm 5: 7-18. (in Japanese).

Ogita, Z., 1964 Improved agar gel media for thin layer electrophoresis. Med. J. Osaka Univ. 15: 141-153.

Ogita, Z., 1965a Genetic control of multiple esterases in Musca domestica. Japan. J. Genetics 40: $1-14$.

Ogita, Z., 1965b Genetico-biochemical analysis of specific esterases in Musca domestica. Japan. J. Genetics 40: 173-184.

Ozaki, K., and H. Koike, 1965 Naphthyl acetate esterase in the green rice leafhopper, Nephotettix cincticeps UHLER, with special reference to the resistant colony of the organophosphorus insecticide. Japan. J. Appl. Ent. Zool. 9: 53-59.

Veldhuis, H. H.W., and K. van Asperen, 1963 Occurrence and inheritance of esterases in Musca domestica. Entomol. Exp. Appl. 6: 79-87.

Wright, T.R.F., 1963 The genetics of an esterase in Drosophila melanogaster. Genetics 48: 787-801.

Wright, T.R.F., and R.J. MacIntyre, 1963 A homologous gene-enzyme system, esterase 6, in Drosophila melanogaster and D. simulans. Genetics 48: 1717-1726.

Yoshitake, N., and M. Akiyama 1964 Genetical studies on the acid-phosphatase in the blood of the silkworm, Bombyx mori L. Japan. J. Genetics 39: 26-30.

Yoshitake, N., 1964 Genetical studies on the alkaline-phosphatase in the mid-gut of the silkworm, Bombyx mori L. J. Sericult. Sci. Japan 33: 28-33. (in Japanese). 